\title{
ANALISIS FAKTOR EKSTERNAL DAN INTERNAL DALAM MENENTUKAN STRATEGI KEBERLANJUTAN USAHA SENTRA MIE SOUN DESA MANJUNG KLATEN, JAWA TENGAH
}

\author{
Sigit Adhi Pratomo'), Sudiyo Widodo2), Rifqi Syarif Nasrulloh ${ }^{3)}$ \\ 1) Manajemen Perpajakan, Universitas Widya Dharma Klaten, Jawa Tengah, Indonesia \\ 2,)Pendidikan Pancasila dan Kewarganegaraan, Universitas Widya Dharma Klaten, Jawa \\ Tengah, Indonesia \\ 3)Universitas Nahdlatul Ulama Yogyakarta
}

\begin{abstract}
Abstrak
Penelitian ini dilakukan untuk mengetahui alternatif strategi yang harus dilakukan berdasarkan kondisi faktor-faktor internal dan eksternal yang terkait saat ini untuk mewujudkan keberlanjutan usaha yang dipertimbangan melalui aspek lingkungan, ekonomi dan sosial. Penelitian dilakukan di Desa Manjung, Klaten, Jawa Tengah yang dikenal sebagai desa sentra penghasil mie soun. Ada 82 produsen mie soun di desa Manjung dengan berbagai skala produksi. Penelitian ini menggunakan analisis External Factor Evaluation (EFE) dan Internal Factor Evaluation (IFE) serta matriks Internal Eksternal (IE) untuk menentukan strategi pilihan yang tepat. Stability strategi merupakan strategi pilihan yang didapatkan dari hasil analisis EFE, IFE dan matriks IE. Matriks SWOT digunakan untuk menentukan dan menyusun langkah implementasi strategi yang terkait dengan pilihan strategi tersebut. Stability strategi dilakukan hingga ancaman yang dimiliki sentra mie soun desa manjung lebih kecil daripada peluang yang ada. Kemandirian dalam penyediaan bahan baku menjadi kunci utama agar keberlanjutan usaha dapat direalisasikan dengan baik.
\end{abstract}

Kata Kunci: Analisis EFE, Analisis IFE, Analisis matriks SWOT, Keberlanjutan

*Correspondence Address : rifqinymph@gmail.com DOI : $10.31604 /$ jips.v6i2.2019.120-134

(C) 2019 Fakultas Keguruan \& Ilmu Pendidikan UM-Tapanuli Selatan 


\section{PENDAHULUAN}

Indonesia merupakan negara agraris yang kaya akan hasil pertanian dan pangannya. Berbagai macam varietas tanaman pokok dan hasil olahan pangan yang mampu di produksi oleh masyarakat Indonesia. Sektor pangan merupakan usaha manusia untuk mengelola lahan dan agroekosistem dengan bantuan teknologi, modal, tenaga kerja, dan manajemen untuk mencapai kedaulatan dan ketahanan pangan, serta kesejahteraan rakyat (Undang-Undang No. 41 Tahun 2009). Produk Domestik Bruto (PDB) sektor makanan dan minuman pada 2016 mencapai Rp 586,5 triliun atau 6,2\% dari total PDB nasional senilai Rp 9.433 triliun. Selain itu, sektor makanan dan minuman selalu tumbuh di atas pertumbuhan Produk Domestik Bruto (PDB) nasional. Pada triwulan III 2017 PDB sub sektor makanan dan minuman tumbuh $9,46 \%$ menjadi $\mathrm{Rp}$ 166,7 triliun, sementara ekonomi Indonesia hanya tumbuh 5,06\% (Katadata.co.id, 2019). Pertumbuhan industri makanan dan minuman ini didorong oleh peran sektor usaha kecil dan mikro dalam menjalankan perekonomian nasional. Pada tahun 2010, jumlah usaha makanan dan minuman di kategori industri kecil dan mikro mencapai 960.305 dan meningkat hingga mencapai 1.614 .149 di tahun 2015 (Mahardika, 2018)

UMKM merupakan salah satu pelaku kegiatan di industri pengolahan pangan dimana dengan adanya proses kegiatan tersebut mampu menyerap banyak tenaga kerja dan meningkatkan situasi daya saing usaha yang ada di lingkungan ekonomi masyarakat menengah, selain itu UMKM juga berperan dalam pendistribusian hasilhasil pembangunan (Kristiyanti, 2012). Namun, pengembangan UMKM masih perlu diperhatikan oleh beberapa pihak seperti dari pemerintah maupun masyarakat agar dapat berkembang lebih kompetitif bersama pelaku ekonomi lainnya (Hafsah, 2004). Keberadaan industri olahan pangan menjadi motor penggerak yang penting bagi pertumbuhan ekonomi masyarakat menengah ke bawah. Salah satu UMKM yang menjadi perhatian yaitu sentra industri Mie Soun Desa Manjung, Klaten, Jawa Tengah. Kegiatan industri di Desa Manjung merupakan kegiatan industri turun menurun karena sudah ada sejak dahulu, saat ini para pelaku industri pangan mie soun merupakan keturunan keempat dari para pendahulunya. Ada sekitar 80 pelaku usaha yang bergerak dalam bidang usaha produksi mie soun 
di Desa Manjung sehingga menjadi sentra industri mie soun di Klaten, Jawa Tengah. Namun, setiap tahunnya ada 2-4 pelaku usaha yang berhenti berproduksi karena berbagai faktor yang mempengaruhi.

Pengelolaan UMKM seringkali dilakukan oleh pelaku itu sendiri karena faktor ketidaksengajaan sehingga pelaku UMKM seringkali tidak memiliki pengetahuan yang memadahi tentang bagaimana menjalankan usahanya (Bismala, 2016). Hal ini menyebabkan rendahnya tingkat keberlanjutan usaha yang dijalankan oleh UMKM. Keberlanjutan usaha yang berkaitan erat dengan pemeliharaan jangka panjang dari sistem yang sesuai dengan pertimbangan lingkungan, ekonomi dan sosial menjadi point penting yang perlu diperhatikan oleh setiap pelaku UMKM (Crane \& Matten dalam Bonn \& Fisher, 2011).

Dengan perkembangan jaman yang ada, saat ini segala lini kehidupan manusia telah terhubung dengan berbagai teknologi dan inovasi. Perubahan tersebut turut berpengaruh terhadap perekonomian dan tidak terkecuali dunia industri (Mahardika, 2018). Dalam pengertian yang lebih luas, keberlanjutan berkaitan dengan dampak dimana tindakan yang diambil saat ini sama sebagaimana pilihanpilihan tersebut tersedia dimasa mendatang (Aras \& Crowther, 2008). Keberlanjutan usaha menjadi faktor yang sangat penting dikarenakan terus berkembangnya faktor internal dan faktor eksternal yang mempengaruhi kegiatan usaha UMKM (Radarwati, 2010). Oleh karena itu, diperlukan adanya upaya pengelolaan yang berkelanjutan bagi pelaku UMKM khususnya sentra industri mie soun Desa Manjung, Klaten, Jawa Tengah. Analisis faktor internal dan faktor eksternal yang mempengaruhi keberlanjutan usaha mie soun Desa Manjung perlu diidetifikasi agar mendapatkan status posisi usaha terhadap strategi keberlanjutan usaha. Oleh karena itu, penelitian ini memiliki tujuan yaitu 1) mengidentifikasi faktor internal dan faktor eksternal yang ada di UMKM sentra industri mie soun Desa Manjung, Klaten. 2) menganalisis strategi keberlanjutan usaha untuk pengembangan UMKM sentra industri mie soun Desa Manjung.

Berdasarkan urgensi strategi keberlanjutan usaha yang ada di UMKM mie soun Manjung, maka hipotesis penelitian ini yaitu 1) Terdapat faktorfaktor yang mempengaruhi secara multidimensi terhadap pengelolaan dan 
aktivitas usaha UMKM mie soun

Manjung. 2) Diperlukan implementasi strategi keberlanjutan secara sistematis pada UMKM mie soun Manjung.

\section{METODE PENELITIAN}

Waktu dan tempat penelitian

Penelitian ini dilakukan pada tahun 2019 dengan obyek UMKM sentra industri mie soun di Desa Manjung, Klaten, Jawa Tengah. Desa Manjung merupakan salah satu ikon Kabupaten Klaten, Jawa Tengah karena dikenal sebagai desa penghasil mie soun terbesar di Klaten. Ada 80 pelaku usaha mie soun yang terdaftar di Desa Manjung yang mayoritas merupakan masyarakat asli Desa Manjung.

\section{Jenis Data dan Pengumpulan Data}

Jenis Data

Data yang digunakan dalam penelitian ini yaitu data primer dan data sekunder. Data primer dan sekunder yang digunakan mencakup data-data yang berkaitan dengan faktor internal eksternal UMKM. Faktor internal yang mempengaruhi UMKM meliputi sumber daya yang ada, kemampuan UMKM, kualitas produk, efisiensi usaha, respon terhadap pelanggan dan inovasi (Bernroider, 2002). Faktor eksternal UMKM meliputi faktor ekonomi, sosial, politik, teknologi, dan kompetitif atau pesaing (David, 2010).

\section{Pengumpulan Data}

Pengumpulan data primer dilakukan melalui beberapa tahapan yaitu observasi lingkungan, wawancara hingga memberikan kuesioner terhadap responden yang memiliki peranan penting di lingkungan Desa Manjung, terutama bagi para pelaku usaha mie soun. Data sekunder dikumpulkan melalui penelusuran berbagai hasil studi, buku-literatur, informasi internet, referensi, statistik, terbitan jurnal, surat kabar, dan sumber lainnya yang mendukung (Kristanto, 2018).

\section{Metode Analisis Data}

Analisis EFE dan IFE

Analisis External Factor Evaluation (EFE) dan Internal Factor Evaluation (IFE) bertujuan untuk menghimpun informasi-informasi yang berkaitan dengan faktor eksternal dan internal yang mempengaruhi UMKM. Analisis matriks EFE dan IFE ini dapat dikembangkan dalam lima langkah sederhana yaitu : 1) membuat daftar faktor eksternal dan internal yang akan dianalisis. Dalam penelitian ini, faktor internal yang akan di analsisi merujuk pada indikator yang ditentukan oleh (Bernroider, 2002), meliputi sumber daya yang ada, kemampuan UMKM, 
kualitas produk, efisiensi usaha, respon terhadap pelanggan dan inovasi. Sedangkan faktor eksternal mengacu pada pendapat David (2010) yang meliputi faktor ekonomi, sosial, politik, teknologi, dan kompetitif atau pesaing, 2) memberikan bobot pada setiap faktor yang berkisar 0,0 (Tidak Penting) hingga 1,0 (Sangat penting), 3) Beri peringkat 1-4 pada setiap faktor untuk mengindikasikan 1 = sangat lemah, $2=$ lemah, 3 = kuat, 4 = sangat kuat, 4) Kalikan bobot setiap faktor dengan peringkatnya untuk menentukan skor bobot bagi masing-masing indikator, dan 5) Jumlahkan skor bobot masingmasing indikator untuk memperoleh skor bobot total (Rangkuti, 2008).

\section{Analisis Matriks IE}

Matriks Internal Eksternal (IE) didasarkan pada dua dimensi kunci: skor bobot IFE total pada sumbu $\mathrm{x}$ dan skor bobot EFE total pada sumbu y. Setiap divisi dalam suatu organisasi harus membuat Matriks IFE dan Matriks EFE dalam kaitannya dengan organisasi. Skor bobot total yang diperoleh dari divisi-divisi tersebut memungkinkan susunan Matriks IE di tingkat perusahaan. Pada sumbu x dari Matriks IE, skor bobot IFE total 1,0 sampai 1,99 menunjukkan posisi internal yang lemah; skor 2,0 sampai 2,99 dianggap sedang; dan skor 3,0 sampai 4,0 adalah kuat. Serupa dengannya, pada sumbu y, skor bobot EFE total 1,0 sampai 1,99 dipandang rendah; skor 2,0 sampai 2,99 dianggap sedang; dan skor 3,0 hingga 4,0 adalah tinggi (David, 2011).

\section{Analisis Matriks SWOT}

Matriks SWOT adalah sebuah alat pencocokan yang penting yang membantu para pengambil keputusan mengembangkan empat jenis strategi: Strategi SO (kekuatan-peluang), Strategi WO (kelemahan-peluang), Strategi ST (kekuatan ancaman), dan Strategi WT (kelemahan-ancaman). Mencocokkan faktor-faktor eksternal dan internal utama merupakan bagian tersulit dalam mengembangkan Matriks SWOT dan membutuhkan penilaian yang baik dan tidak ada satu pun paduan yang paling benar. Oleh karena itu tujuan dari analisis matriks SWOT adalah untuk menghasilkan strategi-strategi alternatif yang masuk akal, bukan untuk memilih atau menentukan strategi mana yang terbaik (Ghazinoory et al, 2007; David, 2011).

\section{PEMBAHASAN DAN HASIL}

Analisis EFE dan IFE

Analisis External Factor Evaluation (EFE) dilakukan dengan cara menganalisis faktor-faktor eksternal yang telah ditentukan, antara lain mencakup peluang dan ancaman yang 
ada di lingkungan UMKM sentra industri

mie soun manjung. Berdasarkan

wawancara yang sudah dilakukan oleh

beberapa pihak yang terkait, maka

berikut hasil analisis EFE yang sudah di

rangkum dalam tabel 1.

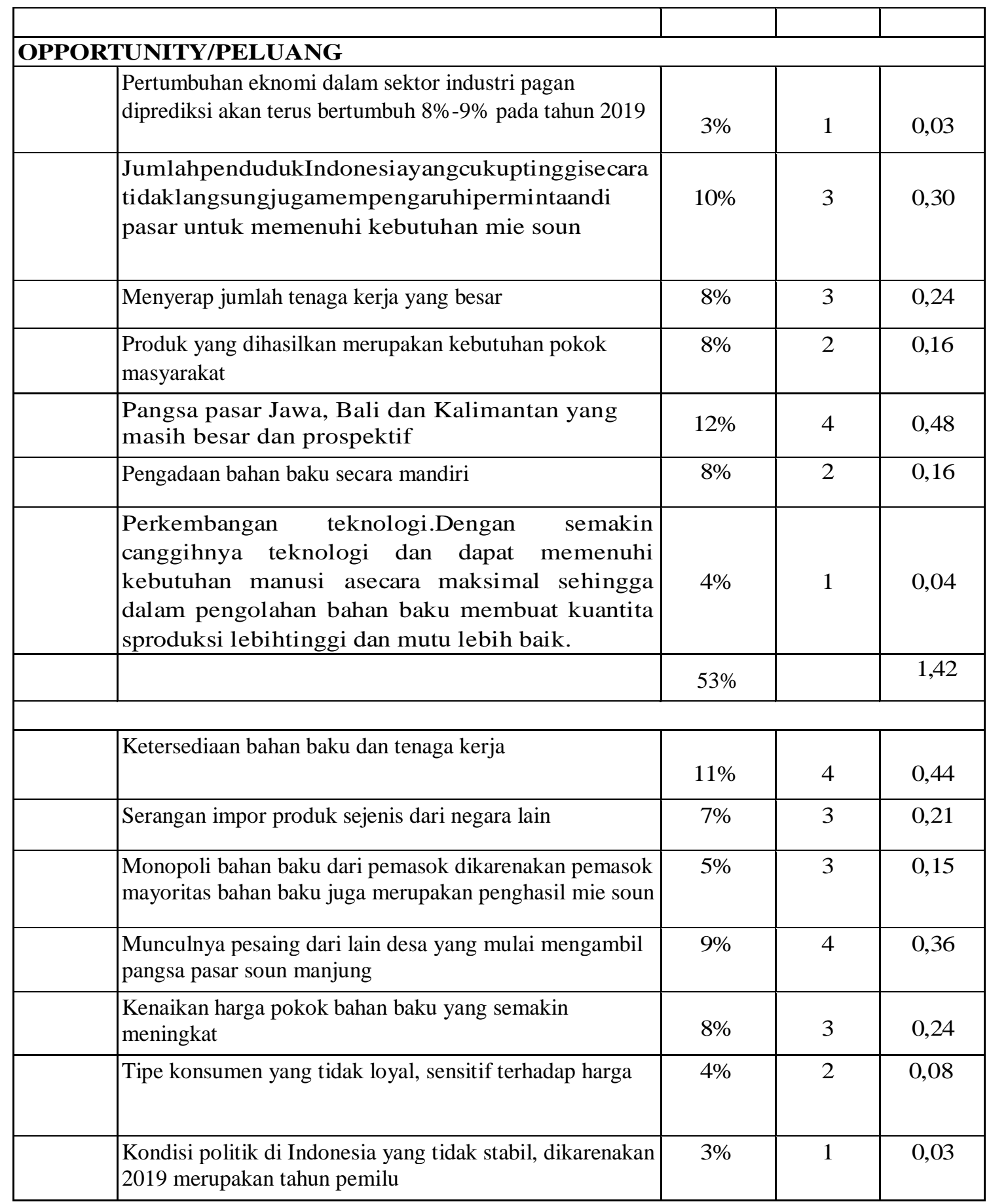


Dari hasil di atas, menunjukkan bahwa peluang yang dimiliki oleh UMKM sentra industri mie soun manjung lebih besar daripada ancaman yang ada. Para responden menganggap bahwa pangsa pasar Jawa, Bali, Kalimantan yang masih sangat prospektif dapat di realisasikan, dilanjutkan dengan jumlah penduduk masyarakat Indonesia yang besar sehingga kedua hal tersebut merupakan peluang yang sangat mendukung keberlanjutan usaha. Total point menunjukkan jumlah bobot dan nilai yang diberikan pada keduaya sebesar 0,48 dan 0,30 , sehingga dapat disimpulkan bahwa jumlah pertumbuhan masyarakat Indonesia dan pangsa pasar di beberapa daerah menjadi prioritas utama. Sedangkan ancaman terbesar ditunjukkan pada item ketersediaan bahan baku dan tenaga kerja dengan total nilai 0,44 , munculnya pesaing dari lain desa yang mengambil pangsa pasar berada diperingkat kedua dengan nilai 0,36, sehingga perhatian terhadap pengelolaan bahan baku dan tenaga kerja serta peningkatan daya saing juga menjadi prioritas pembenahan demi keberlanjutan usaha.

\section{Analisis Internal Factor} Evaluation (IFE) dilakukan dengan cara menganalisis faktor-faktor internal yang telah ditentukan, antara lain mencakup kekuatan dan kelemahan yang ada pada UMKM sentra industri mie soun manjung. Berikut hasil analisis IFE yang sudah di rangkum dalam tabel 2. 
Sigit Adhi Pratomo, Sudiyo Widodo, Rifqi Syarif Nasrulloh

Analisis Faktor Eksternal Dan Internal Dalam Menentukan Strategi Keberlanjutan Usaha

Tabel 2. Hasil Analisis IFE

\begin{tabular}{|c|c|c|c|c|}
\hline \multicolumn{5}{|c|}{ STRENGTH/KEKUATAN } \\
\hline 1 & $\begin{array}{l}\text { Keterampilan SDM sangat mahir dalam proses produksi karena } \\
\text { kegiatan usaha sudah turun temurun, hingga sekarang adalah } \\
\text { generasi ke-4 }\end{array}$ & $15 \%$ & 4 & 0,6 \\
\hline 2 & $\begin{array}{l}\text { Citra baik Desa Manjung sebagai sentra produksi soun yang } \\
\text { berkualitas }\end{array}$ & $12 \%$ & 4 & 0,48 \\
\hline 3 & Kualitas produk yang sudah dikenal oleh banyak pasar & $9 \%$ & 3 & 0,27 \\
\hline 4 & $\begin{array}{l}\text { Memiliki koperasi sebagai wadah kelembagaan antara pengrajin } \\
\text { di Desa Manjung }\end{array}$ & $3 \%$ & 2 & 0,06 \\
\hline 5 & Penggunaan mesin-mesin produksi & $8 \%$ & 3 & 0,24 \\
\hline 6 & $\begin{array}{l}\text { Produk mempunyai ciri khas yang sangat unik yaitu tingkat } \\
\text { kekenyalan, bentuk serat dan warna }\end{array}$ & $9 \%$ & 3 & 0,27 \\
\hline 7 & Kapasitas produksi besar & $9 \%$ & 3 & 0,27 \\
\hline \multirow[t]{2}{*}{8} & Pangsa pasar yang luas & $9 \%$ & 3 & 0,27 \\
\hline & & $74 \%$ & & 2,46 \\
\hline \multicolumn{5}{|c|}{ WEAKNESS/KELEMAHAN } \\
\hline & Proses pengeringan masih mengandalkan cuaca & $11 \%$ & 3 & 0,33 \\
\hline 2 & Penyedia bahan baku masih didominasi dalam satu tempat & $8 \%$ & 2 & 0,16 \\
\hline 3 & Manajemen keuangan dan SDM yang kurang baik & $3 \%$ & 2 & 0,06 \\
\hline \multirow[t]{2}{*}{4} & $\begin{array}{l}\text { Persaingan usaha tidak sehat sesama pengrajin di Desa } \\
\text { Manjung }\end{array}$ & $4 \%$ & 3 & 0,12 \\
\hline & & $26 \%$ & & 0,67 \\
\hline
\end{tabular}


Berdasarkan analisis IFE yang dilakukan, menunjukkan bahwa kekuatan yang dimiliki oleh UMKM sentra industri mie soun manjung lebih besar daripada kelemahan yang ada. Oleh karena itu, dapat diperoleh informasi bahwa UMKM sentra industri mie soun manjung memiliki kekuatan utama yaitu pada ketrampilan dan kemampuan pembuatan mie soun dengan kualitas yang baik, hal tersebut ditunjukkan dengan jumlah nilai bobot tertinggi sebesar 0,6. Selanjutnya citra baik Desa Manjung sebagai penghasil mie soun yang berkualitas menjadi kekuatan diperingkat kedua dengan jumlah nilai bobot sebesar 0,48. Sedangkan kelemahan yang dimiliki meliputi proses pengeringan mie soun yang masih sangat mengandalkan panas matahari dengan jumlah nilai bobot sebesar 0,33 pada peringkat pertama. Selanjutnya penyediaan bahan baku yang masih didominasi pada satu tempat merupakan kelemahan diperingkat kedua dengan jumlah nilai bobot 0,16.

Tabel 3. Matrix EFE dan IFE

\begin{tabular}{|c|c|c|c|c|}
\hline Kuadran & Titik & $\begin{array}{c}\text { Luas } \\
\text { Matrix }\end{array}$ & Ranking & $\begin{array}{c}\text { Prioritas } \\
\text { Strategi }\end{array}$ \\
\hline SO & $\begin{array}{c}2,46: \\
1,42\end{array}$ & 3,4932 & 2 & Ekspansi \\
\hline ST & $2,46:$ & 3,7146 & 1 & Stabil \\
& 1,51 & & 4 & Kombinasi \\
\hline WO & $\begin{array}{c}0,67: \\
1,42\end{array}$ & 0,9514 & 4 & Penciutan \\
\hline WT & $\begin{array}{c}0.67: \\
1,51\end{array}$ & 1,0117 & 3 & \\
\hline
\end{tabular}

Berdasarkan pada tabel 3, diperoleh hasil bahwa alternatif strategi yang dapat diimplementasikan oleh desa sentra mie soun manjung adalah stabil. Prioritas strategi stabil menjadi peringkat pertama berdasarkan nilainilai yang sudah terkumpul pada analisis EFE dan IFE.

\section{Analisis Matriks IE}

Total skor pada analisis matriks EFE yaitu 2,8 dan pada matriks IFE yaitu 3,13 sehingga berdasarkan Matriks Internal Eksternal (IE) maka dapat ditetapkan titik temu kedua skor tersebut pada sel kolom nomor IV yaitu stabilitas hati-hati. Hal tersebut menunjukkan bahwa demi keberlanjutan usaha maka UMKM sentra industri mie soun manjung harus menerapkan strategi yang ditentukan tanpa mengubah arah strategi yang telah ditetapkan. Keputusan stability strategy ini diakui kebenarannya oleh mayoritas pengrajin yang adi di Desa Manjung. 


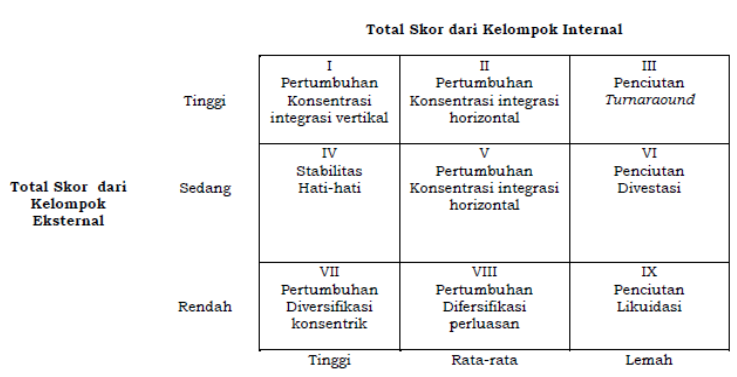

Gambar 1. Matrix IEAnalisis

\section{Matriks SWOT}

Analisis EFE dan dan IFE merupakan salah satu usaha untuk merumuskan strategi yang akan diimplementasikan, lalu dengan analisis SWOT akan dirumuskan beberapa alternatif-alternatif strategi yang sesuai dengan kondisi yang ada berpedoman pada keputusan strategi matriks IE. Berikut ada 4 alternatif strategi yang dapat disajikan dalam matriks SWOT :

\begin{tabular}{|c|c|c|c|}
\hline \multirow{2}{*}{\multicolumn{2}{|c|}{ MATRIKS SWOT }} & \multirow[b]{2}{*}{$\begin{array}{l}\text { Strength } \\
\text { Keterampilan SDM } \\
\text { dan Citra baik Desa } \\
\text { Manjung sebagai } \\
\text { sentra produksi soun } \\
\text { yang berkualitas }\end{array}$} & \multirow[b]{2}{*}{$\begin{array}{l}\text { Weakness } \\
\text { Proses pengeringan masih } \\
\text { mengandalkan cuaca dan Penyedia } \\
\text { bahan baku masih didominasi } \\
\text { dalam satu tempat }\end{array}$} \\
\hline & & & \\
\hline Opportunities & $\begin{array}{l}\text { Jumlah } \\
\text { pendudukIndonesia } \\
\text { yang besar dan } \\
\text { Pangsa pasar Jawa, } \\
\text { Bali dan Kalimantan } \\
\text { yang masih besar } \\
\text { dan prospektif }\end{array}$ & $\begin{array}{l}\text { Mempertahankan } \\
\text { dan meningkatkan } \\
\text { kualitas mie soun } \\
\text { sehingga } \\
\text { menjaga nama baik } \\
\text { dan } \\
\text { menjangkau pasar } \\
\text { yang lebih luas lagi } \\
\text { dengan } \\
\text { mengandalkan nama } \\
\text { baik yang sudah } \\
\text { dimiliki. }\end{array}$ & $\begin{array}{l}\text { Mempersiapkan pengembangan } \\
\text { teknologi untuk lebih } \\
\text { mempermudah proses produksi } \\
\text { agar dapat terus menambah } \\
\text { kuantitas produksi sehingga dapat } \\
\text { memenuhi pangsa pasar yang masih } \\
\text { luas. }\end{array}$ \\
\hline Threats & $\begin{array}{l}\text { Ketersediaan bahan } \\
\text { baku dan tenaga kerja } \\
\text { serta pesaing dari desa } \\
\text { lain }\end{array}$ & 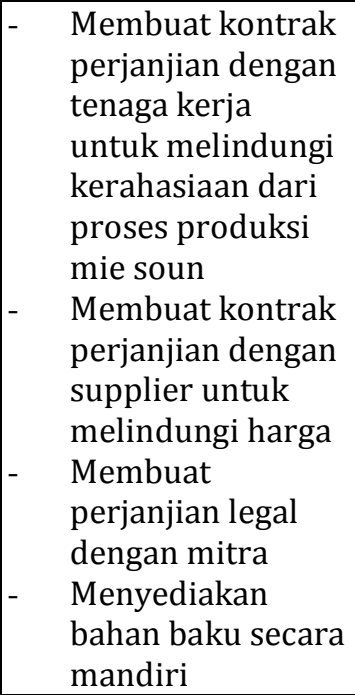 & $\begin{array}{l}\text { Mempersiapkan Pengembangan } \\
\text { unit bisnis untuk dapat menyediaan } \\
\text { bahan baku secara mandiri. }\end{array}$ \\
\hline
\end{tabular}




\section{Pembahasan}

Keberlanjutan usaha merupakan salah satu tujuan jangka panjang yang terus dikejar oleh semua pelaku usaha. Keberlanjutan usaha sangat tergantung pada tindakan yang di ambil saat ini dan menjadi faktor yang sangat penting karena adanya perkembanganperkembangan yang terjadi seiring dengan perubahan faktor eksternal dan internal yang mempengaruhinya. Ketepatan dalam mengambil alternatifalternatif strategi adalah upaya untuk terus mempertahankan keberlanjutan usaha agar dapat tetap memiliki daya saing dalam menghadapi persaingan di pasar yang semakin kompetitif. Faktor eksternal dan internal menjadi faktorfaktor penentu tindakan strategi yang harus di ambil. Secara garis besar, ada 4 alternatif strategi utama yang dapat diimplementasikan yaitu pengembangan/ekspansi, stabil, penciutan/divestasi dan kombinasi.

Berdasarkan analisis External Factor Evaluation (EFE), Internal Factor Evaluation (IFE) dan Matriks Internal Eksternal (IE) yang telah dilakukan memberikan hasil yang sama yaitu alternatif pilihan strategi untuk tidak mengubah arah strategi yang telah ditetapkan dan yang telah dijalankan.
Dalam matriks IE keputusan alternatif pilihan strategi dipertegas dengan pilihan stabilitas hati-hati sehingga sentra mie soun desa manjung harus meningkatkan kewaspadaannya terhadap kelemahan yang dimiliki dikarenakan nilai yang dihasilkan menunjukkan bahwa kekuatan yang dimiliki oleh sentra mie soun desa manjung lebih besar daripada kelemahan yang dimiliki namun tetap perlu diantisipasi, oleh karena itu ada alternatif pilihan strategi selanjutnya yaitu stabil tetapi tetap melakukan penetrasi pasar agar tetap mampu menguasai pasar yang ada dan dapat menguasai pasar yang sudah ditargetkan.

Mengimplementasi strategi yang sudah ditetapkan agar tetap konsisten bukanlah sesuatu yang mudah, oleh karena itu sehubung dengan pilihan strategi stabilitas maka ada beberapa langkah strategi yang dapat dirumuskan agar langkah yang diambil tidak keluar dari strategi yang telah ditetapkan. Berdasarkan matriks SWOT yang telah disusun, kombinasi strategi telah ditentukan agar strategi yang dilakukan lebih jelas implementasinya. Kekuatan dan peluang yang dimiliki sentra mie soun desa manjung menunjukkan 
bahwa masih banyak sekali peluangpeluang pasar yang dapat ambil dan relevan dengan kekuatan yang dimiliki. Mempertahankan dan meningkatkan kualitas mie soun desa manjung sehingga dapat menjaga nama baik desa manjung sebagai desa sentra industri mie soun dengan tujuan mendapatkan jangkauan pasar yang lebih luas lagi dengan mengandalkan nama baik yang sudah dimiliki. Dengan strategi ini, tentu saja kekuatan merek ataupun citra baik desa manjung menjadi faktor yang sangat penting. Menjaga kualitas produk, menjaga hubungan dengan mitra, menjaga hubungan dengan supplier, dan menjaga hubungan antar sesama produsen di desa manjung adalah langkah-langkah nyata yang harus dilakukan oleh semua produsen mie soun yang ada di desa manjung. Selain itu target pasar yang sudah ditentukan dapat perlahan dikuasai dengan cara penetrasi pasar melalui penawaran-penawaran produk secara besar. Hal tersebut sudah dilakukan beberapa produsen dengan memberikan produk mie soun untuk dibandingan dengan produk sejenis di pasar secara cuma-cuma sehingga perbedaan kualitas akan lebih terlihat oleh konsumen. Cara ini dapat terus diimplementasikan pada pasar terget yang masih prospektif.
Sehubung dengan kelemahan terbesar yang dimiliki oleh sntra mie soun desa manjung, mempersiapkan pengembangan teknologi untuk lebih mempermudah proses produksi agar dapat terus menambah kuantitas produksi sehingga dapat memenuhi pangsa pasar yang masih luas merupakan salah satu pilihan strategi yang dapat dilakukan. Produksi mie soun yang sangat tergantung pada panas matahari menyebabkan produksi tidak dapat berjalan dengan normal apabila kondisi cuaca tidak ada panas matahari. Pengembangan teknologi yang dapat melakukan proses pegeringan tanpa panas matahari merupakan salah satu terobosan proses produksi yang dapat menjadi jalan keluar para produsen mie soun desa manjung. Hal tersebut sudah mulai dilakukan oleh beberapa pengrajin dengan membuat alat pengering mie soun yang masih dalam tahap uji coba atau prototipe. Dengan adanya pengembangan teknologi ini, diharapkan kuantitas dan kualitas produksi dapat stabil terjaga sehingga dapat memenuhi kebutuhan pasar yang ada serta memenuhi permintaan pasar yang dijadikan target pangsa pasar selanjutnya.

Ancaman merupakan faktor yang tidak dapat dikendalikan namun dapat 
diantisipasi. Ketersediaan bahan baku dan tenaga kerja serta pesaing dari desa lain merupakan ancaman terbesar, oleh karena itu ada beberapa langkahlangkah yang dapat dilakukan agar dapat mengantisipasi ancaman tersebut. Membuat kontrak perjanjian dengan tenaga kerja untuk melindungi kerahasiaan dari proses produksi mie soun, membuat kontrak perjanjian dengan supplier untuk melindungi harga bahan baku, membuat perjanjian legal dengan mitra serta dapat menyediakan bahan baku secara mandiri agar tidak tergantung oleh desa lain yang menjadi pemasok bahan baku. Secara pengalaman dan ilmu, para produsen mie soun desa manjung juga memiliki kemampuan untuk mengolah bahan mentah menjadi bahan baku pembuatan mie soun, namun hanya ada 1 produsen saja yang sudah mampu memproduksi bahan bakunya sendiri. Hal tersebut dapat menjadi acuan bagi produsen lain agar dapat menyediakan bahan baku secara mandiri. Lebih jelasnya bahwa pemasok bahan baku desa manjung merupakan desa tetangga yang juga memiliki beberapa produsen mie soun. bahan baku yang dikirim ke desa manjung merupakan bahan baku dengan kelas $\mathrm{B}$, sedangkan bahan baku kelas A sudah dipergunakan oleh produsen dari desa tetangga tersebut. Oleh karena itu, membuat perjanjian tertulis dengan semua pihak terkait dan membangun kemandirian dalam penyediaan bahan baku merupakan langkah nyata yang dapat dilakukan untuk mengantisipasi ancaman yang ada.

Penyediaan unit bisnis tersendiri dapat menjadi pilihan strategi yang dapat diimplementasikan agar penyediaan bahan baku secara mandiri dapat direalisasikan. Penyediaan unit bisnis ini dapat dilakukan melalui koperasi bersama yang sudah terbentuk untuk menaungi para produsen mie soun desa manjung. Koperasi dapat berperas sebagai penyedia bahan baku utama bagi para produsen mie soun desa manjung, dengan demikian kemandirian berasaskan dari anggota, untuk anggota oleh anggota dapat direalisasikan.

\section{SIMPULAN DAN SARAN}

\section{Simpulan}

Analisis External Factor Evaluation (EFE) dan Internal Factor Evaluation (IFE) berkesimpulan bahwa pilihan strategi yang terbaik saat ini untuk sentra mie soun desa manjung adalah strategi stabil. Hal tersebut dikarenakan pilihan stabil berada pada peringkat pertama nilai nilai yang 
tertinggi. Hal tersebut terjadi dikarenakan ancaman yang ada lebih besar daripada peluang yang dimiliki walaupun nilainya tidak terpaut jauh. Dalam analisis matriks internal eksternal (IE) memberikan kesimpulan strategi terpilih pada kuadran stabil berhati-hati.

Pilihan stability strategi merupakan strategi yang tepat untuk diimplementasikan pada saat ini dengan cara tidak mengubah arahan strategi yang sudah ditetapkan dan yang sudah dijalankan. Selain itu, penetrasi pasar juga dapat dilakukan dikarenakan relevansi antara peluang dan kekuatan yang dimiliki oleh sentra mie soun desa manjung. Dengan pilihan strategi ini, keberlanjutan usaha yang berlandaskan pada pertimbangan lingkungan, ekonomi dan sosial dapat terealisasikan. Matriks SWOT yang disajikan merupakan langkah nyata para produsen mie soun yang telah dikonfirmasi kebenarannya sehingga stability strategi perlu dilakukan selama ancaman yang ada dapat diturunkan sehingga peluang yang dimiliki lebih besar.

Dengan adanya keputusan yang tepat dengan mengambil stability strategi sebagai pilihan strategi saat ini, diharapkan keberlajutan usaha sentra mie soun desa manjung dapat terus berjalan dan dapat mengimplementasikan strategi selanjutnya yaitu strategi bertumbuh. Dengan demikian, implementasi strategi secara bertahap dan sistematis dapat merealisasikan keberlanjutan usaha dengan baik.

\section{Saran}

Nama baik desa manjung sebagai desa sentra produksi mie soun menjadi salah satu kekayaan yang dimiliki Kabupaten Klaten, hal tersebut memberikan tugas bagi pemerintah setempat untuk menjaga dan menginventariskan kekayaan tersebut. Program inventaris kekayaan tersebut dapa berupa fasilitasi pendaftaran merek kolektif Desa Manjung. Selain itu, Pemerintah juga dapat melakukan pelatihan-pelatihan dan bekerjasama dengan lembaga pendidikan terkait dengan industri olahan pangan (Franita, 2016). Untuk penelitian selanjutnya, dapat meneliti lebih lanjut variabelvariabel yang terkait dengan strategi yang telah diimplementasikan seperti pengaruh citra baik terhadap pemasaran, ataupun Total Quality Management dalam produksi mie soun.

\section{Ucapan Terima Kasih}


Tim peneliti mengucapkan terimakasih kepada DIKTI yang telah mendukung sepenuhnya kegiatan pengabdian masyarakat ini untuk skema Penelitian Dosen Pemula (PDP) tahun anggaran 2019.

\section{Daftar Pustaka}

Aras, G., \& Crowther, D. (2008). Governance and sustainability: An investigation into the relationship between corporate governance and corporate sustainability. Management Decision, 46(3), 433-448.

Bernroider, E. (2002). Factors in SWOT Analysis Applied to Micro, Small-to-Medium, and Large Software Enterprises:: an Austrian Study. European management journal, 20(5), 562-573.

Bismala, L. (2017). Model Manajemen Usaha Mikro Kecil dan Menengah (UMKM) untuk Meningkatkan Efektivitas Usaha Kecil Menengah. Jurnal Entrepreneur dan Entrepreneurship, 5(1), 19-26.

Bonn, I., \& Fisher, J. (2011). Sustainability: the missing ingredient in strategy. Journal of business strategy, 32(1), 5-14.

David, F. R. (2010). Management Strategis Konsep .(D. Sunardu, Trans).

David, F. R. (2011). Strategic management: Concepts and cases. Peaeson/Prentice Hall.

Franita, R. (2016). Analisa pengangguran di indonesia. Nusantara: Jurnal Ilmu Pengetahuan Sosial, 1, 88-93.
Ghazinoory, S., Esmail Zadeh, A., \& Memariani, A. (2007). Fuzzy SWOT analysis. Journal of Intelligent \& Fuzzy Systems, 18(1), 99108.

Hafsah, Mohammad Jafar, 2004, Upaya Pengembangan Usaha Kecil dan Menengah (UKM), Infokop 25, 40-44.

https://databoks.katadata.co.id/datapublish/20 18/01/30/industri-makanan-danminum-tumbuh-di-atas-pdb-nasional

Kristanto, V. H. (2018). Metodologi Penelitian Pedoman Penulisan Karya Tulis Ilmiah:(KTI). Deepublish.

Kristiyanti, M. (2012). Peran strategis usaha kecil menengah (UKM) dalam pembangunan nasional. Majalah Ilmiah Informatika, 3(1), 63-89.

Mahardika, R. B., (2018). Mengenal Industri Makanan dan Minuman di Era Industri 4.0. Forbil Institute, Yogyakarta. ISBN 978-602-52952-2-5

Radarwati, S., Baskoro, M. S., Monintja, D. R., \& Purbayanto, A. (2010). Analisis Faktor Internal-Eksternal dan Status Keberlanjutan Pengelolaan Perikanan Tangkap di teluk Jakarta. Jurnal Teknologi Perikanan dan Kelautan, 1(2), 33-46.

Rangkuti, F. (2008). Analisis SWOT: Teknik Membedah Kasus Bisnis cetakan ke lima belas, Penerbit PT. Gramedia Pustaka Utama Jakarta.

Undang-Undang No. 41 Tahun 2009 Tentang Perlindungan Lahan Pertanian Pangan Berkelanjutan 